\title{
IMPACT OF SOME SOIL AMENDMENTS ON PROPERTIES OF SALT AFFECTED CALCAREOUS SOIL AND SALINITY HARMFUL IN TOMATO PLANT (Lycopersicon esculentum)
}

\author{
S. A. E. Abdelrazek \\ Soil Salinity Department, Alexandria Soil, Water and Environment Research Institute, \\ Agriculture Research Center (ARC), Giza, Egypt \\ Samad_saad@yahoo.com \\ Received: Sep. 30,2018 \\ Accepted: Oct. 24,2018
}

\begin{abstract}
An experiment was carried out in plastic pots under greenhouse condition during (2) successive season to investigate the effect of the organic manures (compost, peat moss, chicken and pigeon manures) or soil conditioners (vermiculite and perlite) on some properties of saline calcareous soil and tomato plant enzymes. The obtained results manifested that application of the aforementioned amendments improved soil aggregates, $p H, E C, S P$, cation and anion and availability of $K$. Likewise it decreased the activity of Catalase, Peroxidase and Superoxide dismutase tomato plants. The most beneficial influence of the above-mentioned parameters was observed with addition of peat moss, chicken manure and soil conditioners.
\end{abstract}

Key words: Borg El Arab, Calcareous soil, catalase, peroxidase and superoxide dismutase (SOD)

\section{INTRODUCTION}

Borg El Arab an area as a desert lands represent a marginal soils having various problems and normally poor in nutrient elements (Abdelrazek S. A. E. (2014).

Organic fertilizers are required for clean and safe organic food production all over the world; Addition of organic manures to soils plays an important role in improving physical, chemical and biological characteristics of soil and maintains soil fertility (Sadovnikova et al., 2011).

The decomposition of different organic manures in soil produces different products which increase the availability forms of soil nutrients (Eyras et al., 1998). The organic manures also stimulate the biodegradation through increasing the population and activities of microorganisms in soil (Burger et al., 2015).

Salinity is the major environmental stress and is one of the major factors limiting plant growth and productivity
(Bohnet and Jensen, 2009). High salt concentration in particular $\mathrm{Na}^{+}$which deposit in the soil resulting in decreasing soil porosity and consequently reducing soil aeration and water conductance (Mahajan and Tuteja, 2015).

High salt accumulation in the soil can alter the basic texture of the soil thereby decreasing soil porosity and consequently reduced soil aeration and water conductance (Mhajan and Tuteja, 2015). So, the addition of organic fertilizers in the present investigation or the soil conditioners to the saline calcareous soil could improve the soil health in the short run, soil aeration, soil quality in the long run, Soil fertility, nutrient availability and reduced same plant pests (Audrey, 2013).

Some of the antioxidant enzymes and Catalase (CAT) peroxidase (POX) and superoxide dismutase (SOD) were increased in plants grown on salt affected soil (Shao et al., 2007). 
Superoxide dismutase metabolizes oxygen (O-2) redicals to hydrogen peroxide $\left(\mathrm{H}_{2} \mathrm{O}_{2}\right)$. Thus protecting cells from damage (Dalmia and Sawhnay, 2014). Catalase, peroxidase and a variety of peroxidases catalyze the subsequent breakdown of $\mathrm{H}_{2} \mathrm{O}_{2}$ to water and oxygen (Varshney et al., 2011).

Mittova et al., (2003) reported that the activities of antioxidative enzymes were increased in plants grown under water salt stress, and found correlation between these enzymes levels and salt tolerance.

El-Massry and Negm (2015) studied the effect of organic amendments (cattle manure, poudrette and chicken manure on tomato growth. They found that the chicken one residues treatment were superior for increasing $\mathrm{N}$ uptake and enhancing growth of tomato plant cultivated in calcareous soil. Moreover, El-Missery and Hassan (2003) noticed reduction in $\mathrm{Na}$ and $\mathrm{Cl}$ ions level in cabbage and spinach leaves grown in saline soil amendments with chicken manure as well as farmyard manures or compost. So the aim of this investigation was to appear the beneficial effect of some soil amendments (Organic fertilizers, soil conditioners) an improving the physical and chemical properties of salt affected calcareous soil brought from Borg El Arab and reducing the salinity harmful on Tomato plants

\section{MATERIAL AND METHODS}

\section{An experiment}

The present study was carried out at Soil Salinity Alkalinity Laboratory green house in Alexandria during two successive spring season through 2015/2016 and 2016/2017.

To study the effect of applied organic manures (compost, Patmos, chicken) and soil conditioners[ perlite+ vermiculite ]on saline calcareous soil properties, the antioxidant defense systems of tomato plants (Lycopersicon esculentum L.Cv. Castle -Roke). Tomato seeds were brought from the Horticulture, Research Institute, Giza, Egypt.

Thirty tow pots contain $5 \mathrm{~kg}$ mixed soil for each pot was divided into eight main groups to represent 8 treatments with 4 replicates. Ten seeds of tomato were planted in each pot, thinned after growth to 4 seedlings. The applied treatment included:

1. Saline calcareous soil

2. Saline calcareous soil mixed with Loamy soil (1:1 w/w).

3. Saline calcareous soil mixed with compost (1:1 w/w).

4. Saline calcareous soil mixed with peat moss (1:1 w/w).

5. Saline calcareous soil mixed with chicken manure [ $(0.25+0.75) \mathrm{w} / \mathrm{w}]$

6. Saline calcareous soil mixed with pigeon manure + washed calcareous soil [ $(0.25+0.75) \mathrm{w} / \mathrm{w}]$

7. Saline calcareous soil mixed with vermiculite (1:1 w/w).

8. Saline calcareous soil mixed with perlite and vermiculite $[(0.5+0.5) \mathrm{w} /]$

\section{Soil Analysis}

Particle size distribution (granuleometric analysis) of the studied soil samples was deformed by the dry sieving method described by Kilmer and Alexander (2013). Soil reaction was determined in the soil paste (1:2.5) (soil: water w/v), using a Bekman bench type pH-meter (Richards, 1954)

Electrical conductivity (E.C) in the saturated extracts of the different soil samples was determined according to in Richards (1954).

Cations and Anions were determine according to Pag et al. (1982) 
Irrigation with Tap water (Fresh water)

\section{Plant Analysis}

Extraction and determination of certain antioxidant enzymes:

Enzyme extraction:

Sample preparation was described by Mandhania et al. (2016) A fresh leaf sample (250 $\mathrm{mg})$ was frozen in liquid nitrogen and finely ground by pestle in a chilled morlar. Ten m/s of $100 \mathrm{mM}$ phosphate buffer $\left(\mathrm{KH}_{2} \mathrm{PO}_{4} / \mathrm{K}_{2} \mathrm{HPO}_{4}\right) \mathrm{pH}$ 7.0 containing $0.1 \mathrm{mM}\left(\mathrm{Na}_{2}\right.$ EDTA) and 0.1 $g$ of PVP were added to the frozen sample. The homogenate was then filtered through chose cloth then centrifuged at $15000 \mathrm{~g}$ for $10 \mathrm{~min}$. The supernatant centrifuged at $18000 \mathrm{~g}$ for 10 min. The resulted supernatant was collected and stored at $4^{\circ} \mathrm{C}$ for analysis of Catalase (CAT) peroxidase (POX) and superoxide dismutase (SOD)

\section{Superoxide dismutase (SOD) activity}

Absorbance was measured at $560 \mathrm{~nm}$ using a Spectronic 20 spectrophotometer (Asada, 1992).

- Catalase (CAT) activity

Absorbance at $240 \mathrm{~nm}$ as a consequence of $\mathrm{H} 2 \mathrm{O} 2$ Consumption and was expressed according to (Ashraf and Harris 2004).

- Peroxidase (POD) activity

The increase in absorbance due to the dehydrogenation of guaiacol was monitored at $470 \mathrm{~nm}$ (Scott et al., 1987).

\section{RESULTS AND DISCUSSION}

\section{Soil Analysis}

1-1. Pysical Properties of the Soil

Granulometric analysis

The analysis of soil samples collected from Borg El Arab area revealed that the percentage of fine particles with diameters ranged from 0.05 to $0.01 \mathrm{~mm}$ were relatively low in the un-amended saline soil (Table 1).

Table (1): Soil particles distribution (\%) of the studied soil as affected by different treatments

\begin{tabular}{|c|c|c|c|c|c|c|}
\hline \multirow{2}{*}{ Diameter $(\mathrm{mm})$} & $<0.05$ & $0.05-0.1$ & $0.1-0.25$ & $0.25-0.50$ & $0.5-1$ & $1-2$ \\
\hline & \multicolumn{6}{|c|}{$\begin{array}{l}\text { particles distribution } \\
(\%)\end{array}$} \\
\hline Saline calcareous soil & 1.877 & 8.53 & 8.139 & 8.368 & 30.271 & 32.125 \\
\hline $\begin{array}{l}\text { Saline calcareous soilt } \\
\text { Loamy soil }\end{array}$ & 11.353 & 10.511 & 3.186 & 16.455 & 20.819 & 39.871 \\
\hline $\begin{array}{l}\text { Saline calcareous soilt } \\
\text { compost }\end{array}$ & 15.529 & 17.488 & 5.126 & 12.189 & 22.168 & 33.827 \\
\hline $\begin{array}{l}\text { Saline calcareous soilt } \\
\text { peat moss }\end{array}$ & 6.062 & 16.241 & 5.152 & 10.519 & 29.248 & 33.948 \\
\hline $\begin{array}{l}\text { Saline calcareous soilt } \\
\text { chicken manure }\end{array}$ & 4.674 & 10.512 & 4.108 & 9.581 & 23.991 & 47.921 \\
\hline $\begin{array}{l}\text { Saline calcareous soil+ } \\
\text { pigeon manure }\end{array}$ & 5.551 & 7.424 & 3.115 & 15.828 & 24.177 & 55.180 \\
\hline $\begin{array}{l}\text { Saline calcareous soilt } \\
\text { vermiculite }\end{array}$ & 7.251 & 17.271 & 5.149 & 10.218 & 23.727 & 36.919 \\
\hline $\begin{array}{l}\text { Saline calcareous soil+ } \\
\text { perlite+ vermiculite }\end{array}$ & 8.138 & 10.589 & 2.945 & 5.951 & 13.920 & 59.221 \\
\hline
\end{tabular}


The addition of organic manures or soil conditioners to that saline calcareous soil increased the percentage of micro aggregates with particle diameter of 1-2 $\mathrm{mm}$ reaching above $5.57 \%-84.49 \%$ in all amendments soils as compared with their corresponding saline un- amended soils (Table 1). Such effect was arranged according to the following order perlite + vermiculite>pigeon manure $>$ chicken manure $>$ loamy soil $>$ vermiculite $>$ saline calcareous soil $>$ peat moss>compost.

The increase abundance in the size of soil particles might be attributed to the aggregation of medium particles after treatments of soil amendments wherever the different organic manures has abundance of organic contents. Similar results have been obtained by Xue Rong and Tifayun (1999).

\section{1-2. Chemical properties of the soils \\ a- $\mathrm{pH}$}

Table (2) shows that, the addition of organic fertilizers or the soil conditioners to the saline calcareous soil slightly increased the $\mathrm{pH}$ values. The values of the $\mathrm{pH}$ in the amended soils ranged from 8.33 and 7.98. The highest value of $\mathrm{pH}$ was recorded in the soil amended with perlite + vermiculite. The increments of the $\mathrm{pH}$ values (Fig 1) of the amended soils might be ascribed to the detected slightly higher levels of $\mathrm{HCO}^{3-}$ obtained from fertilizers and conditions.

\section{b- Electric Conductivity (E.C)}

The date of Electric Conductivity are compiled in Fig. (2) and Table (2) and varied from $4.51 \mathrm{dSm}^{-1}$ in saline calcareous soil to $2.46 \mathrm{dSm}^{-1}$ in peat moss treated soil. The greatest increase in E.C (4.51 $\left.\mathrm{dSm}^{-1}\right)$ valve recorded in saline soil was due to its highest contents of $\mathrm{Na}$ and $\mathrm{Cl}$ ions. Addition of different organic fertilizers or soil conditioners to the calcareous saline soil decreased the E.C values Fattah and Abdelrazek (2014) found a similar results.

The reduction in the E.C values in the amended soils was concomitant with the marked decrease in $\mathrm{Na}$ and $\mathrm{Cl}$ ions and the obvious increases in $\mathrm{Ca}, \mathrm{Mg}$ and $\mathrm{K}$ ions as well as bicarbonates (Table 3 ). These results are agreed with those reported by Ammal et al. (2016). who observed a reduction in E.C value after application of organic amendments.

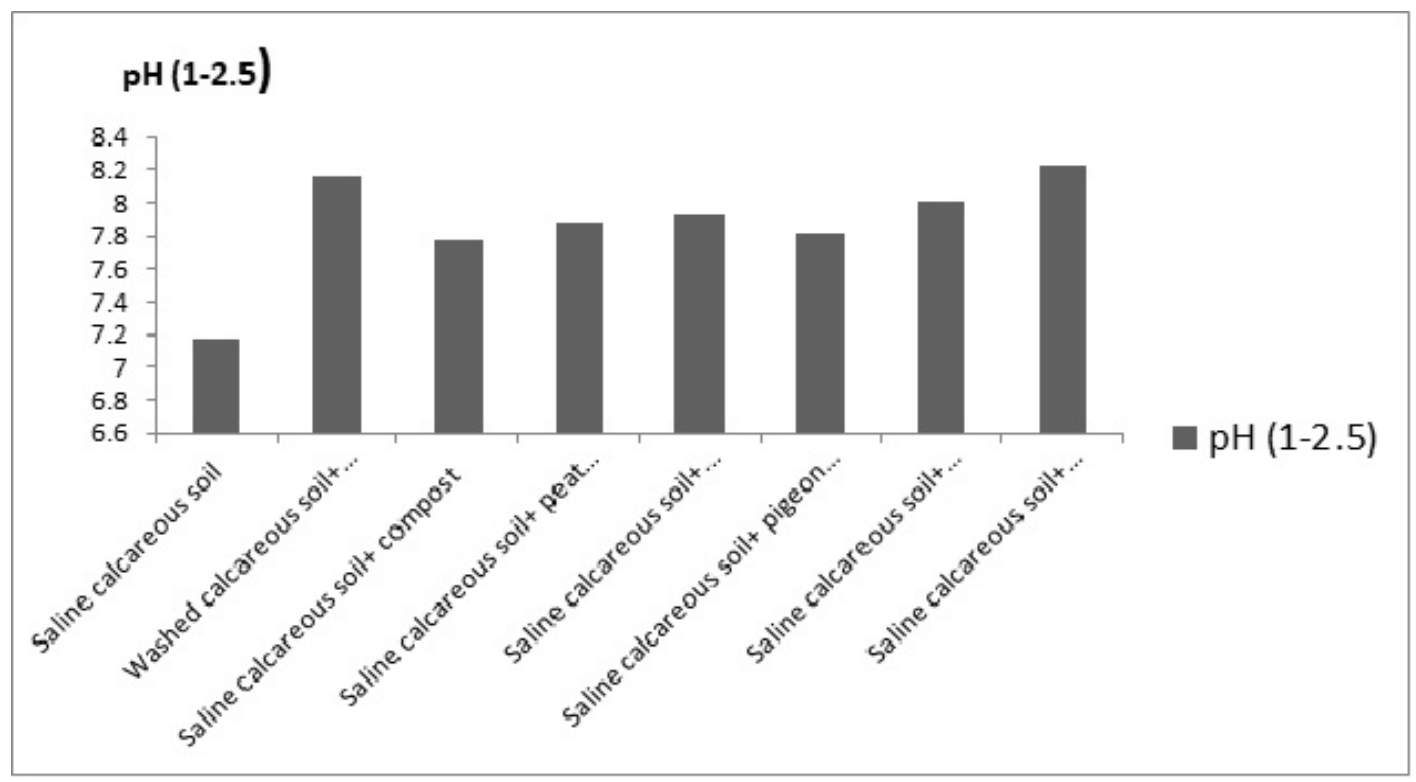

Fig (1). pH (1-2.5) of the studied soil as affected by different treatments 
Table (2): chemical properties of the studied soils as affected by different treatments

\begin{tabular}{|l|c|c|c|c|}
\hline \multicolumn{1}{|c|}{ Treatment } & $\begin{array}{c}\mathrm{pH} \\
(1-2.5)\end{array}$ & $\begin{array}{c}\mathrm{E} . \mathrm{C} \\
(\mathrm{ds} / \mathrm{m})\end{array}$ & $\begin{array}{c}\mathrm{K}^{*} \\
\mathrm{mgKg}^{-1}\end{array}$ & $\begin{array}{c}\text { S.P } \\
(\%)\end{array}$ \\
\hline Saline calcareous soil & 7.18 & 4.51 & 25.95 & 35.33 \\
\hline Washed calcareous soil+ Loamy soil & 8.16 & 3.09 & 19.45 & 42.40 \\
\hline Saline calcareous soil+ compost & 7.78 & 3.28 & 23.21 & 41.01 \\
\hline Saline calcareous soil+ peat moss & 7.89 & 2.46 & 16.21 & 51.42 \\
\hline Saline calcareous soil+ chicken manure & 7.92 & 3.61 & 19.88 & 56.41 \\
\hline Saline calcareous soil+ pigeon manure & 7.82 & 2.68 & 16.79 & 54.81 \\
\hline Saline calcareous soil+ vermiculite & 8.01 & 3.88 & 12.21 & 45.01 \\
\hline Saline calcareous soil+ perlite+vermiculite & 8.23 & 3.01 & 36.02 & 62.39 \\
\hline
\end{tabular}

*K: Available Potassium in soils

Table (3): Soluble Cations and Anions of the studied soils as affected by different treatments

\begin{tabular}{|l|c|c|c|c|c|c|c|}
\hline \multirow{2}{*}{ Treatment } & \multicolumn{4}{|c|}{ Cation (meq/L) } & \multicolumn{3}{c|}{ Anion (meq/L) } \\
\cline { 2 - 8 } & $\mathrm{Ca}+$ & $\mathrm{Mg} 2+$ & $\mathrm{K}+$ & $\mathrm{Na}+$ & $\mathrm{SO}_{4}-$ & $\mathrm{HCO}_{3}^{-}$ & $\mathrm{Cl}^{-}$ \\
\hline Saline calcareous soil & 7.21 & 8.21 & 1.19 & 11.15 & 18.85 & 2.7 & 6.21 \\
\hline $\begin{array}{l}\text { Saline calcareous soil+ } \\
\text { Loamy soil }\end{array}$ & 8.55 & 12.01 & 1.33 & 5.18 & 19.90 & 4.02 & 3.14 \\
\hline $\begin{array}{l}\text { Saline calcareous soil+ } \\
\text { compost }\end{array}$ & 18.02 & 13.09 & 1.42 & 4.41 & 27.67 & 4.04 & 5.23 \\
\hline $\begin{array}{l}\text { Saline calcareous soil+ } \\
\text { peat moss }\end{array}$ & 9.02 & 7.89 & 1.24 & 4.78 & 14.51 & 3.41 & 5.01 \\
\hline $\begin{array}{l}\text { Saline calcareous soil+ } \\
\text { chicken manure }\end{array}$ & 7.60 & 13.71 & 5.41 & 3.49 & 20.08 & 5.21 & 4.92 \\
\hline $\begin{array}{l}\text { Saline calcareous soil+ } \\
\text { pigeon manure }\end{array}$ & 10.22 & 14.92 & 2.86 & 3.49 & 20.86 & 5.61 & 5.02 \\
\hline $\begin{array}{l}\text { Saline calcareous soil+ } \\
\text { vermiculite }\end{array}$ & 29.61 & 17.92 & 5.82 & 2.24 & 44.99 & 5.72 & 4.88 \\
\hline $\begin{array}{l}\text { Saline calcareous soil+ } \\
\text { perlite+ vermiculite }\end{array}$ & 11.40 & 12.61 & 2.21 & 7.66 & 25.65 & 4.51 & 4.22 \\
\hline
\end{tabular}




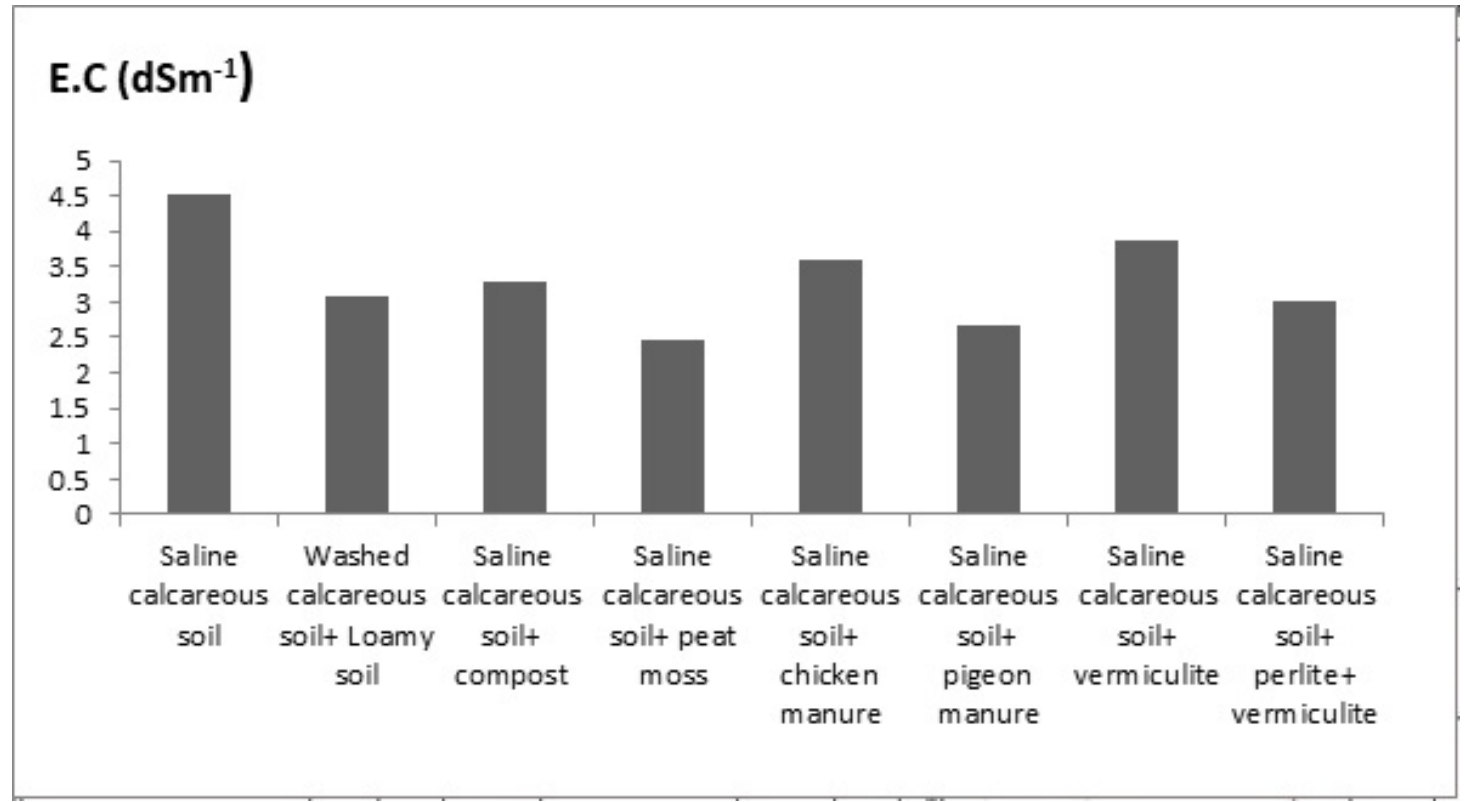

Fig (2). E.C ( $\left(\mathrm{dSm}^{-1}\right)$ of the studied as affected by different amendments

\section{c- Saturation Percent (S.P)}

The addition of different conditioners as a soil amendment into calcareous saline soil markedly increased its saturation percentage (Table 2). Such effect was more pronounced in the saline calcareous soil supplied with perlite + vermiculite followed by chicken manure. Pigeon manure, peat moss, vermiculite, compost and loamy soil. Saline Calcareous soil received no amendments has the lowest S.P value. In this respect, Nelson, (1991) found that perlite and vermiculite are able to increase S.P and provide suitable water to the whole plant.

Also, Bhatti et al. (2010) reported that farmyard amended soil able to provide available water to the cultivated plant. This might be due to the increase in soil organic matter content in the provided organic manures.

In general, addition of manures or soil conditioners might increase soil water holding capacity and porosity as well as changing pore size distribution thereby reducing bulk density and penetration resistance. Therefore, additions of organic manures or soil conditioners improve aggregates stability; thereby improve soil mechanical properties (Fig 3).

\section{d- Cation}

Soil salinity is one of the important factors leading to severe crop loss every year (Misra et al., 2011). Additions of organic fertilizer or soil conditioners to saline calcareous soil nullify the adverse effects of salt as well as improved the physical and chemical properties (Sharma et al., 2014).

\section{1- Calcium Ion Level $\left(\mathrm{Ca}^{2+}\right)$}

It is evident from Table (2) that, $\mathrm{Ca}^{2+}$ level of saline calcareous soil supplied with either organic fertilizer or soil conditioners was markedly higher than that observed in saline calcareous soil. The maximum increase in $\mathrm{Ca}^{2+}$ level was observed in soil amended with vermiculite. It was about 4 folds of $\mathrm{Ca}^{2+}$ level in saline soil. However, the increase in $\mathrm{Ca}^{2+}$ levels ranged from one to 2.7 folds in the other treatments (Table 2) and (Fig 4). 


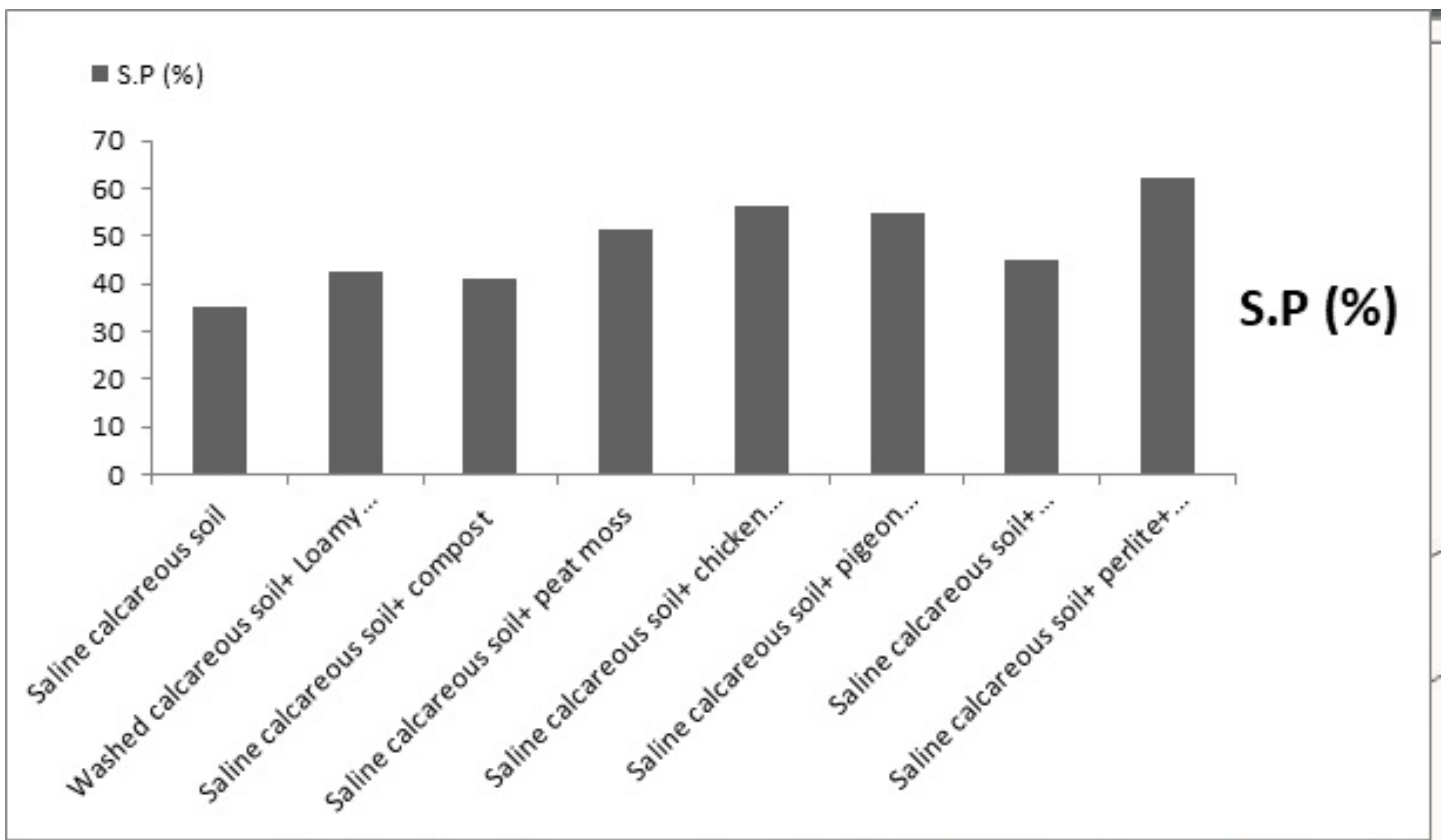

Fig (3). S.P (\%) of the studied soils as affected by different amendments

\section{2- Potassium Ion Level $\left(\mathrm{K}^{+}\right)$}

The variable changes in $\mathrm{K}^{+}$levels of un- amended saline calcareous soil was recorded in Table (2), Addition of organic fertilizers or soil conditioners decreased that $\mathrm{K}+$ content of the treated saline calcareous soil. The greatest level of $\mathrm{K}+$ was recorded in the soil amended with vermiculite thus may be attributed to the $\mathrm{Mg}^{2+}$ higher content of vermiculite and perlite followed by chicken manure. On the other hand, application of vermiculite achieved the highest influence on increasing the soluble $\mathrm{K}^{+}$(Fig 4) in the soil, that may be ascribed to higher $\mathrm{K}^{+}$ content of vermiculite clay minerals (Peterson et al., 1991a).

\section{3- Magnesium Ion Level $\left(\mathrm{Mg}^{2+}\right)$}

The data presented in Table (3) show that, the addition of organic fertilizers or soil conditioners increased the level of $\mathrm{Mg}^{2+}$ in the amended saline calcareous soils. Such increase was much more pronounced in salty soil amended with vermiculite followed by pigeon manure then chicken manure, compost, loamy soil, perlite +vermiculite, peat moss and saline calcareous soil (Fig 4). They may be attributed to the $\mathrm{Mg}^{2+}$ higher content of vermiculite and organic manure (Nelson, 1996).

\section{e- Anion}

\section{1- Bicarbonate $\left(\mathrm{HCO}_{3}{ }^{-}\right)$}

Date in Table (3) show that, application of organic fertilizers or soil conditioners markedly increased the bicarbonate content in saline calcareous soil. The highest value of bicarbonate was observed in vermiculite and pigeon manure amended soil. Generally, it has been observed in the present investigation that additive of organic fertilizers or soil conditioners to saline calcareous soil obviously increased $\mathrm{Ca}^{2+}$, $\mathrm{Mg}^{2+}$ and $\mathrm{K}^{+}$ions as well as bicarbonate concentration with marked decreases in $\mathrm{Na}$ and $\mathrm{Cl}$ ions. 


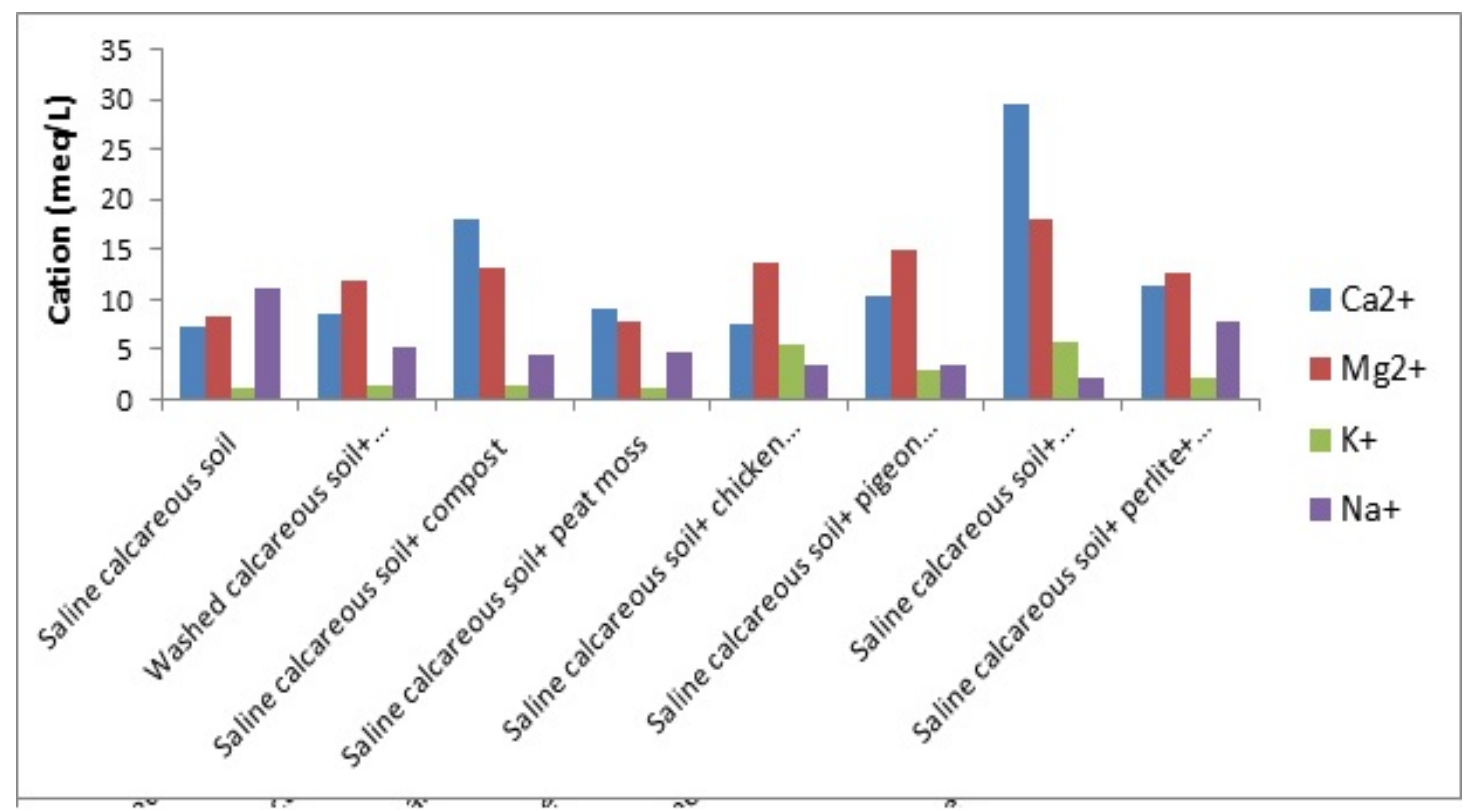

Fig (4). Cation (meq/L) of the studied soils as affected by different amendments

The greatest level of $\mathrm{Ca}^{2+}, \mathrm{Mg}^{2+}$ or $\mathrm{K}^{+}$ ions was recorded in saline calcareous soil supplied with vermiculite (Table 2). This was attributed to the higher content of these ions in vermiculite (Kang et al., 2014). Moreover, Nimje and Jagdish (1981) reported that farmyard increased the available $P$ and $K$ of the treated soil. Also, Singh and Barar (1988), Found that total organic carbon and available $P$ of the soil treated with Azolla and Eichornia composts and farmyard were significantly increased over the contents of the untreated one Moreover, Kahlown and Azam (2013) Postulated that. Farmyard manure reduced soil Sodicity and Salinity and increased E.C of soil.

There is no doubt that the ameliorate of saline calcareous soil by the investigated applied organic manures or the soil conditioners is closely related to fertilizers properties which provide the treated soil with organic and/or inorganic nutrients as well as growth promoting substance, (Abdel-Rahman et al., 2009) Also, Sharma et al. (2014) Postulated that various organic manures can reclaim and improve the physical and chemical properties of the saline soil.

\section{2- Chloride ion level ( $\left.\mathrm{Cl}^{-}\right)$}

Saline soil was rich in $\mathrm{Cl}^{-}$(6.2 meq /L); however the addition of organic fertilizers or soil conditioners reduced the levels of Clions in the amended soils (Table 3). The greatest reduction in $\mathrm{Cl}$ - level was recorded in loamy soil followed by soil amended with perlite + vermiculite (Fig 5).

\section{F- Available Potassium in soils}

Results in this study showed that (SOD) activity (Table 4). in stressed tomato received no amendments significantly surpassed that one grown in saline calcareous soil mixed with to loamy soil, by more than 3-fold Some researchers also, suggest that salt stress led to a decrease in (SOD) activity in salt sensitive plants or to an increase in salt tolerant ones (Rout and Shaw 2011). On the other hand, the activity of (SOD) was significantly decreased in tomato seedlings grown in amended saline soils (Table 4). Such effect might be attributed 
to the reduction in salt level in the amended soils which results from decrease in sodium adsorption ratio, uptake and transport and / or increase in soil moisture content. Furthermore, salinity stimulates the accumulation of the reactive oxygen (ROS) including $\left(\mathrm{H}_{2} \mathrm{O}_{2}\right)$ in plant cells. The metabolism of $\left(\mathrm{H}_{2} \mathrm{O}_{2}\right)$ is dependent on various functionally interrelated antioxidant enzymes such as catalase, phenol peroxidase and superoxide dismutase. These enzymes are involved in elimination of $\left(\mathrm{H}_{2} \mathrm{O}_{2}\right)$ from the stressed plant cells (kim et al., 2015).

Data in Fig. (7) and Table (4) illustrated the changed in the activity of antioxidant enzymes (catalase (CAT) peroxidase (POX) and superoxide dismutase (SOD)) . These results revealed that the activities of the previously mentioned enzymes were significantly increased in stressed tomato plant grown in saline calcareous sandy soil. However it significantly reduced in that soil treated with the different amendments.

The increase in the activities of phenol proxidases (POX), catalases (CAT) and superoxide dismutase (SOD) in stressed tomato plant might suggest their strong implication in the elimination of $\left(\mathrm{H}_{2} \mathrm{O}_{2}\right)$ formed in plant cells.

They seemed to be the most important antioxidants in the defense system of tomato plant. Different trends of peroxidases activity in the leaves of sensitive and tolerant rice plants grown under saline condition has been regarded by Dionisio-Sese and Tobila (2014). In addition, higher activities of SOD, peroxidase and catalase were recorded in cultivated Nacl stressed species of Lycopersicon pennellii (Jauany et al., 1996) as well as in the moderately saltTolerant cotton plant (Ben Amor et al., 2015). It has been reported that the oxidative damage in some halophytes resulted from an enhancement in (catalase (CAT) peroxidase (POX) and superoxide dismutase (SOD)) enzyme activities (Ben Amor et al., 2015).

On the other hand, adding organic manures or soil conditioners markedly reduce the activities of some antioxidant enzyme such as superoxide dismutase SOD, Catalase, as well as Phenol peroxidase (POX) (Table 4) in tomato.

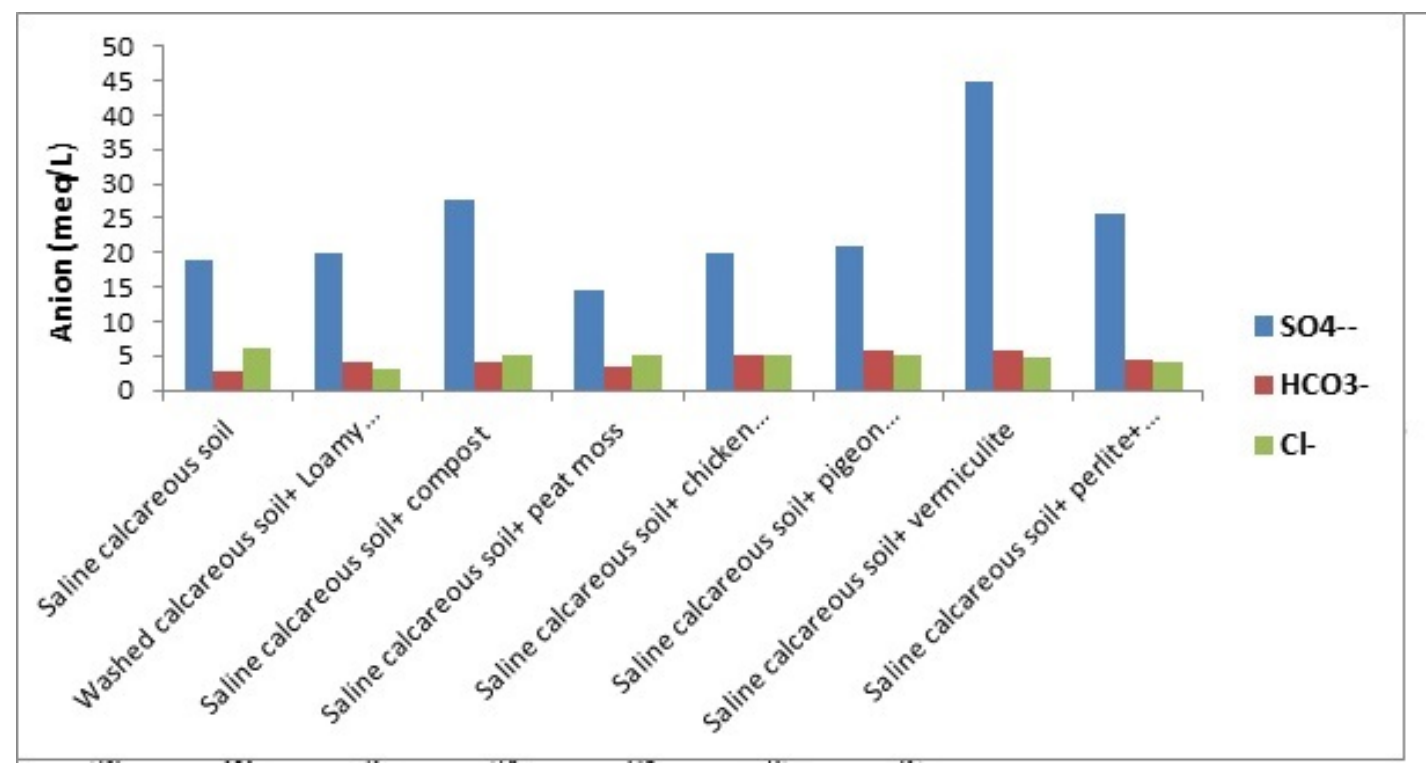

Fig (5). Anion (meq/L) of the tested soil as affected by different treatment 
Various organic manures or soil conditioners amendments nullify the stress effects on the plant cells. Meanwhile, the activities of the antioxidant enzymes were significantly reduced as compare with those of plant grown in the saline soil. Organic manures or soil conditioner supplied the soil with organic carbon, vitamins, and hormones, available nutrients as well as increased the soil moisture content thereby increased the tolerant of plants on one hand and decreased the salt levels in the amended soils on the other hand. Furthermore, addition of manures or conditioners decreased the absorption rate of salts stress on plants (decrease salinity level).

A-biotic stress, such as salinity stress cause molecular damage to plant cells either directly or indirectly through the formation of SOD In the present study, the plants exposed to salinity showed a significant increase in CAT and POX activity and a significant decrease in CAT and POX activity with increase of potassium levels Fig (6). The enzymes assayed are scavengers of free radical species. Hydrogen peroxide is converted to oxygen and water by CAT and POX, which use ascorbate as the hydrogen donor. In conclusion, the results of the present study clearly showed that there was scavenging enzymes in tomato under different salinity stress and high potassium levels.

Antioxidant defiance mechanism Antioxidant enzymes exposure to salt stress can increase oxygen -cellular damage due to the increased (ROS) generation (Mittler, 2012).

The phospholipids membranes are impermeable to charged $\left(\mathrm{O}^{-{ }_{2}}\right)$ molecules, therefore superoxide dismutase (SOD) are present for the removal of superoxide $\left(\mathrm{O}_{2}{ }_{2}\right)$ radicals who are formed (Alscher et al., 2017) superoxide dismutase (SOD) is the first defense agent against reactive oxygen species (ROS) as it is the major scavenger of $\left(\mathrm{O}^{-{ }_{2}}\right)$ (Almoguere et al., 1995).

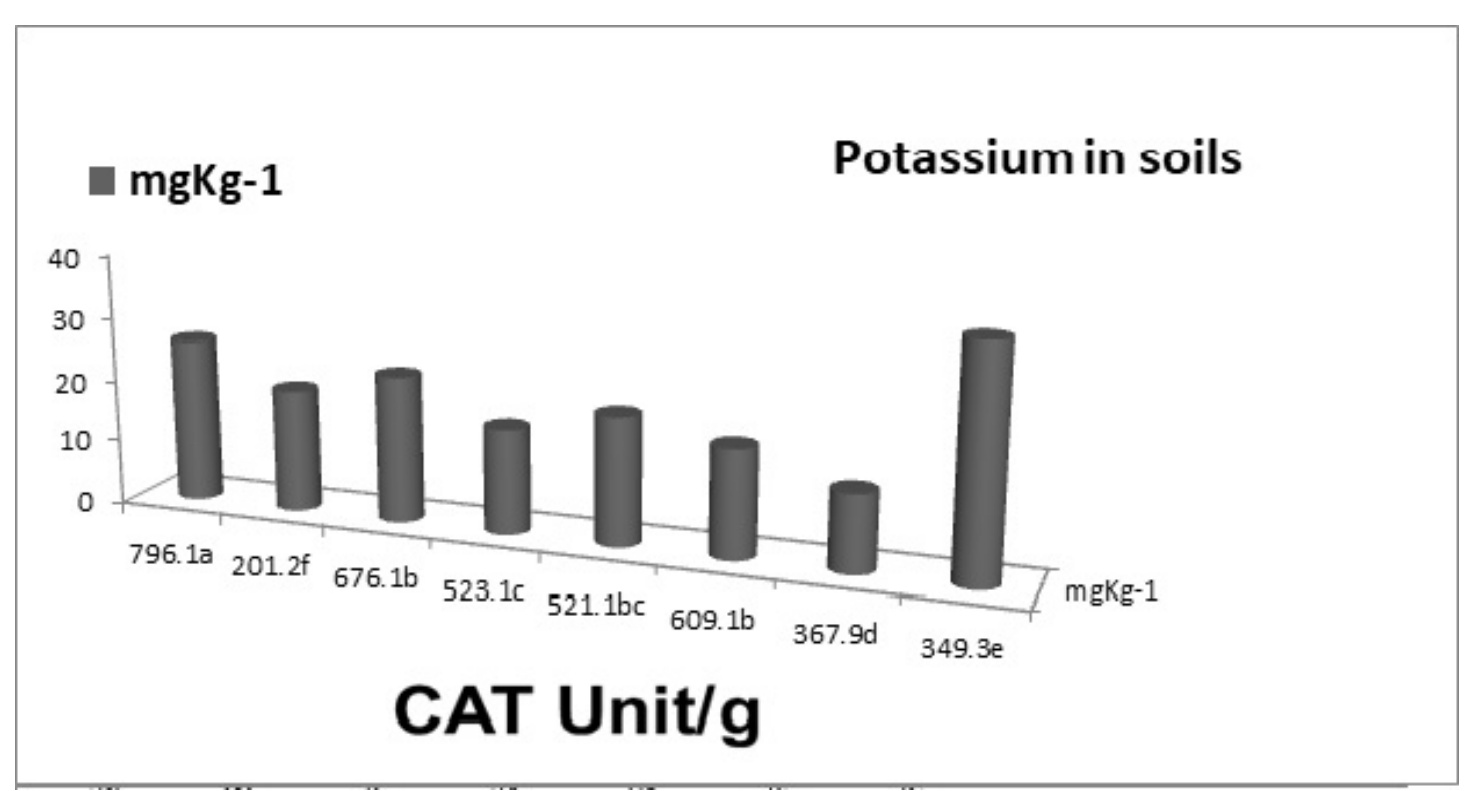

Fig (6). Relationship between Catalase enzymes in plant and available potassium in soils. 
Table (4): Effect of Saline soil amendments different organic fertilizer or soil conditioners on the activity of catalase (CAT) peroxidase (POX) and superoxide dismutase (SOD) of tomato plant after 40 days from sowing.

\begin{tabular}{|l|c|c|c|}
\hline \multirow{2}{*}{ Treatment } & \multicolumn{3}{c|}{ Tomato } \\
\cline { 2 - 4 } & $\begin{array}{c}\text { CAT } \\
\text { (Unit/g) }\end{array}$ & $\begin{array}{c}\text { POX } \\
(\text { Unit/gb) }\end{array}$ & $\begin{array}{c}\text { SOD } \\
\text { (Unit/g) }\end{array}$ \\
\hline Saline calcareous soil & $1196.3 \mathrm{a}$ & $99.8 \mathrm{a}$ & $796.1 \mathrm{a}$ \\
\hline $\begin{array}{l}\text { Saline calcareous soil+ Loamy } \\
\text { soil }\end{array}$ & $842.4 \mathrm{~d}$ & $27.7 \mathrm{f}$ & $201.2 \mathrm{f}$ \\
\hline Saline calcareous soil+ compost & $982.9 \mathrm{~b}$ & $49.9 \mathrm{c}$ & $676.1 \mathrm{~b}$ \\
\hline $\begin{array}{l}\text { Saline calcareous soil+ peat } \\
\text { moss }\end{array}$ & $997.1 \mathrm{~b}$ & $17.8 \mathrm{~g}$ & $523.1 \mathrm{c}$ \\
\hline $\begin{array}{l}\text { Saline calcareous soil+ chicken } \\
\text { manure }\end{array}$ & $396.6 \mathrm{f}$ & $34.3 \mathrm{~d}$ & $521.1 \mathrm{bc}$ \\
\hline $\begin{array}{l}\text { Saline calcareous soil+ pigeon } \\
\text { manure }\end{array}$ & $842.3 \mathrm{~d}$ & $37.3 \mathrm{~d}$ & $609.1 \mathrm{~b}$ \\
\hline $\begin{array}{l}\text { Saline calcareous soil+ } \\
\text { vermiculite }\end{array}$ & $398.3 \mathrm{c}$ & $55.87 \mathrm{~b}$ & $367.9 \mathrm{~d}$ \\
\hline $\begin{array}{l}\text { Saline calcareous soil+ perlite+ } \\
\text { vermiculite }\end{array}$ & $576.1 \mathrm{e}$ & $54.2 \mathrm{~b}$ & $349.3 \mathrm{e}$ \\
\hline L.S.D value at 5\% level & 1.8 & 1.8 & 1.8 \\
\hline
\end{tabular}

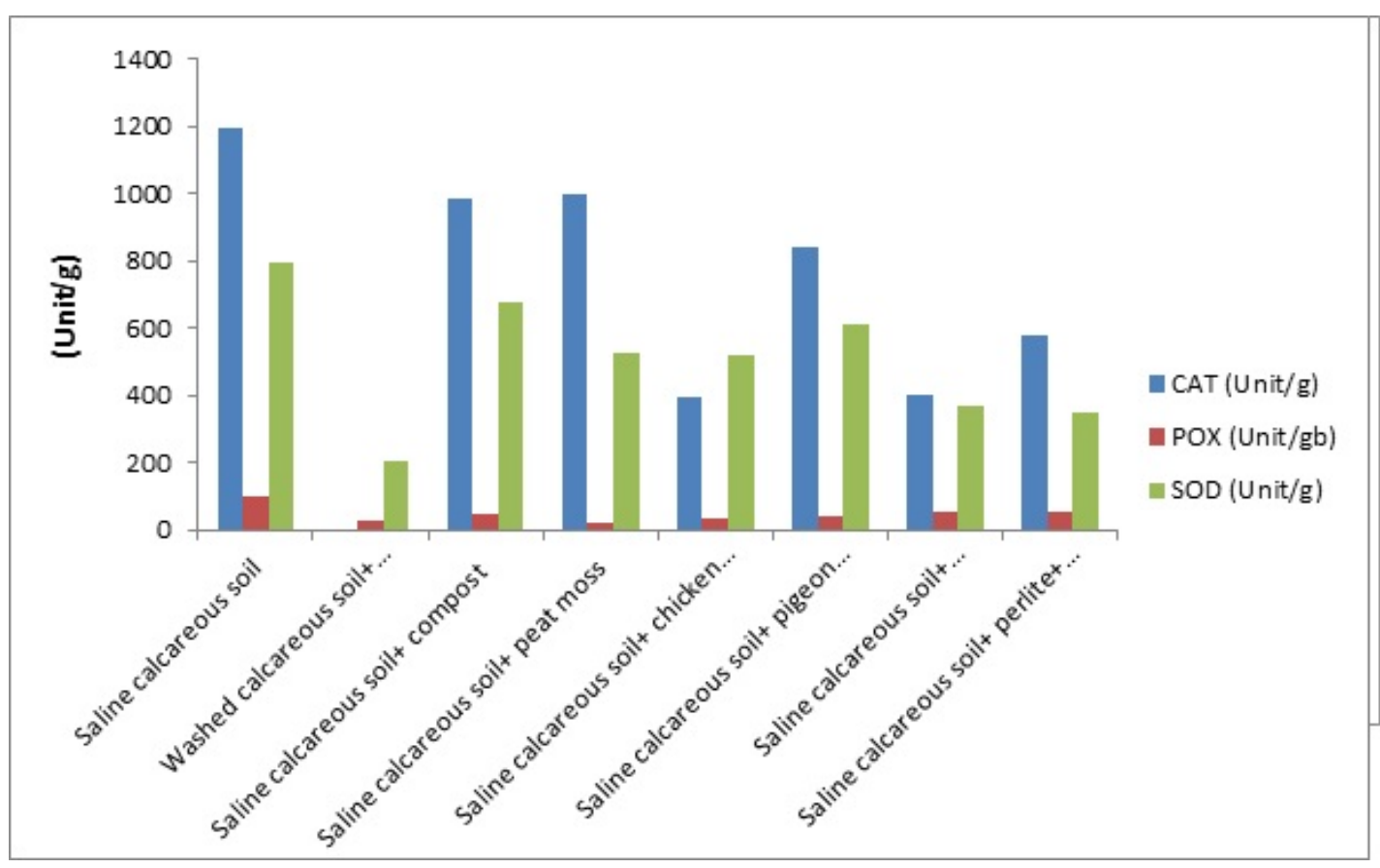

Fig (7). Effect of Some amendments (organic fertilizer and soil conditioners) on the Enzymes activity of Tomato plants 


\section{REFERENCES}

Abdelrazek, S. A. E. (2014). Effect of Wastewater Irrigation on Plant Enzymes and Soil Health Assessment in Borg ElArab Region, Ph.D. thesis University of Sadat City.54-58

Abdel-Rahman, H. A., M. A. Dahab and M. A. Mostafa (2009). Impact of soil amendments of intermittent evaporation, moisture distribution and salt redistribution in saline - sodic clay soil columns. Soil-Science. 16(11): 793-802.

Almoguere, C., M.A. Coca and L. Jouanin (1995). Differential accumulation of sunflower tetrabiquitin mRNA during zygotic embryogenesis and developmental regulation of their heatshock response. Plant Physiol., 107:765-773

Alscher, R.G., J.L. Donahue and C.L. Cramer (2017). Reactive oxygen species and antioxidants relationship in green cells. Pysiol. Plant. 100:224233

Ammal, V.B., P.P. Mahendran and G. Arunachalam (2016). Reclamation of sea water introduced soil. J. o Tropical Agric. 36 (12):53-54

Asada, K. (1992). Ascorbate peroxidase a hydrogen peroxide scavenging enzyme in plants Physiol. Plant., 85:232-241

Ashraf, M. and P.J.C. Harris (2004). Potential biochemical indicators of salinity tolerance in plants. Plant Sci 166:3-16

Audrey, L., L. Harrier, P. Wallace, C. A. Watson and M. Wood (2013). Effect of composting manure and other organic wastes on soil processes and pest disease interactions Repor. Scottich Agric College.8:22-33

Ben Amor, M., K. Ben Hamed, A. Debez, C. Grignon and C. Abdelly (2015). Physological and antioxidant response of the perennial halophyte Crethmum maritimum to salinity. Plant Sci.,168:889-899

Bhatti, A. U., Q. Khan, A. H. Gurmani and M. T. Khan (2010). Effect of organic manure and chemical amandments on soil properties and crop yield on a salt affected Entisol. Pedosphere, 15:46-51

Bohnet, H.J. and R.G. Jensen (2009). Metabolic engineering for increased salt tolerance. Aust. J. Plant Phsiol. 23:661-667

Burger, M., L.E. Jackson, E.J. Lundquist, D.T. Louie, R.L. Miller, D.E. Rolston and K.M. Scow (2015). Microbial responses and nitrous oxide emissions during wetting and drying of organically and conventionally managed soil under tomatoes Biology and fertility of soils. Springer Verlag, GMBH Heideberg, Germany, 42(2):109118

Dalmia, A. and V. Sawhnay (2014). Antioxidant defense mechanism under drought stress in wheat. Physio Mol Biol. Plants 10:109-114

Dionisio-Sese, K.L. and S. Tobila (2014). Antioxidant responses of rice seedling to salinity stress. PInt Sci., 135:1-9

El-Massry, A.A. and M. A. Negm (2015). Effect of organic amendments on some properties of calcareous soil and barley growth. J. Agric. Sci. Mansoura Univ., 11:434-439

El-Missery, T.A. and M.M. Hassan (2003). Competitive response to salinity between salt sensitive and salt tolerant tomato cultivars .Egypt.J.Hort.28:79-89

Eyras., M.C., C.M. Rostagno and G.F. Defosse (1998). Biological evaluation of seaweed Composting, 6 (4):74-81.

Fattah1, M.K S. and A. E. Abdelrazek (2014). The Improvement of the Quality of Irrigation Water Contaminated with Heavy Metals in the Borg El Arab, J. o Water Resource 
and Protection, 6: 1703-1715 http://dx.doi.org/10.4236/jwarp.2014.61 8153

Jaksonm, M. I. (1962). Soil chemical Analysis. Constable and comp. Lad. England.1:122-126

Jauany, C., B. Colomb and M. Bose (1996). Long term effects of potassium fertilization on fields and fertility status of calcareous soils of south west Ferance. European J. Agron.,5:287-294

Kahlown, M.A. and M. Azam (2013). Effect of saline drainage effluent on soil health and crop yield. Agric water Management 62(2): 17-138

Kang, J.Y., H. Lee and K. H. Kim (2014). Physical and chemical properties of inorganic horticultural substrates used in Korea. Avta hort., 644: 237-239

Kim, S,Y., J. W. Lim, M.R. Par, T. Kim, I.I. Park and Y.W. Seo (2015). Enhanced antioxidant enzymes are associated with reduced hydrogen peroxide in barly roots under salt strees. J. Biochem. Mol. Biol, 38:218224.

Mahajan, S. and N. Tuteja (2015). Cold, salinity and drought stresses: an overview. Arch Biochem Biophys 444:139-58.

Mäkelä, P., M. Kontturib, E. Pehua and S. Somersaloa (1999). Photosynthetic response of drought and salt stressed tomato and turnip rape plants to foliarapplied glycinebetaine. Physiol Plant 105:45-50

Mandhania, S., S. Madan and V. Sawhney (2016). Antioxidant defense mechanism under salt stress in wheat seedlings. Plant Biol. 50:227-231.

Mhajan, S. and N. Tuteja (2015). Cold, salinity and droght stresses, An overview, Archives of Biochemistry and Biophysics. 444:139-158

Misra, A.N., S.M. Sahu, I. Meera, N.D. Mohatra and Misra (2011). Root growth of salt susceptible and a salt resistant rice (Oryza sativa L.) during sessdling establishment under $\mathrm{NaCl}$ salinity. Agron Crop Sci. 178:9-14

Mittler, R. (2012). Oxidative stress, antioxidants and stress tolerance.Trends. Plant Sci.7:405-410.

Mittova, V., M. Tal, M. Volokita and M. Guy (2003). up regulation of the leaf mitochondrial and peroxisomal antoxidative systems in response to salt-induced oxidative stress in the wild salt- tolerant tomato species Lycopersicon pennellii plant cell. 26:845-856.

Nelson, P.V. (1996). Assessment and correction of the alkalinity problem associated with Palabora vermiculite. J Am Soc Hort Sci 94:664-667.

Nelson, P.V. (1991). Greenhouse operation and management, $4^{\text {th }}$ ed . Prentice Hall., Englewood Cliffs, N.J.

Nimje, P.M. and Jagdish Seth (1986). Effect of phosphorus farmyard manure and nitrogen on some soil properties in soyabean-miaze sequence. J. Agric. Sci. comb., 107: 555

Page, A. L., R.H. Miller and R. Keeny (1982). Methods of soil analysis. Part 2. Chemical and microbiological properties Agron. Monograph no. 9, ASA, Madison, Wisc. U. S. A.

Peterson, T.A., M.D. Reinsel and D.T. Krizek (1991a). Tomato (Lycopersicon esculentum Mill cv. 'Better Bush') plant response to root restriction. Alteration of plant morphology. J Exp Bot 42:1233-1240.

Richards, L.A. (1954). Diagnosis and Improvement of Saline and Alkali Soils. USDA Handbook. 5:17-24.

Rosolem, C.A. and D.S. Mikkelsen (2013). Potassium Absorption and Partitioning in Cotton as Affected by Periods of Potassium Deficiency. J. Plant Nutri. 14:1001-1016. 
Rout, N.P. and B.P. Shaw (2011). Salt tolerance in aquatic macrophytes possible involvement of the antioxidative enzymes. Plant. Sci., 160:415-423.

Sadovnikova, L., E. Olabbongm, $\mathrm{O}$. Lakimonko, I. Nilsson, J. Person and D. Oplovm (2011). dynamic transformation of sewage sludge and farmyared manure compounds 2 . Copper, Lead and cadmium forms in incubated soils. Utilization of waste organic matter. Agric, Ecosystem Environ 58:127-132.

Scott, M.D., S.R. Meshnick and J.W. Eaton (1987). Superoxide dismutaserich bacteria. J. Biol. Chem. 262: 3640-3645.

Shao, H.B., L.Y. Chu, Z.H. Lu and C.M. Kang (2007). Primary antioxidant free radical scavenging and redox signaling pathways in higher plant cells. Int J Biol Sci 4:8-14

Sharma, P., B.R. Chipa and S.R. Sharma (2014). Impact of organic manure and mineral nutrients on physic-chemical properties and yield of wheat (triticum aestivum L.) grown under saline soil. Book-chapter. Conference-paper.2-5.

Varshney, R.K., K.C. Bansal, P.K. Aggarwal, S.K. Datta and P.Q. Craufurd (2011). Agricultural biotechnology for crop improvement in a variable climate: hope or hype Trends Plant Sci 16:363-71

Xue Rong and Tifayun (1999). Effect of organic materials on composition characteristics of micro aggregates in albic soil and their nutrient content. Chinese Journal of Applied Ecology. 10 (1): $42-44$ 
تأثير بعض محسنات التربة الجيرية على خواص الاراضى المتأثرة بالاملاح و تقليل ضرر الملوحة على نبات الطماطم

\section{سعد عبد الصمد السيد عبد الرازق}

معمل بحوث الاراضى الملحية والقلوية بالاسكندرية - معهة بحوث الاراضى والمياه والبيئة - مركز البحوث الزراعية -

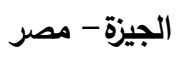

الملخص العربى

يهاف هذا البحث الى تقليل أضرار الملوحة على نبات الطماطم وذلك بدراسة سلوك انتاج شتلات الطماطم باستخدام

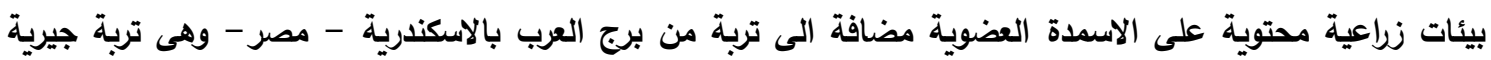

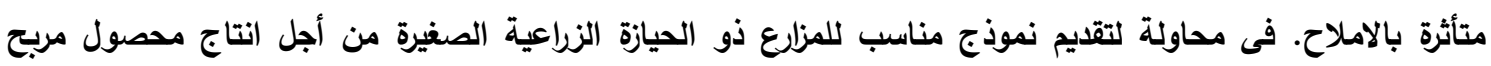

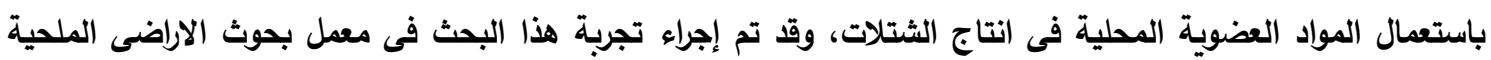

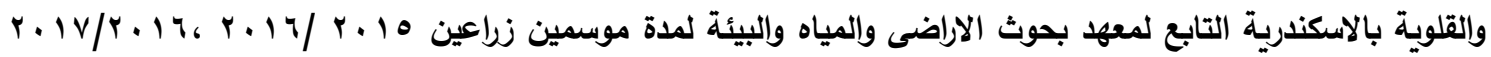

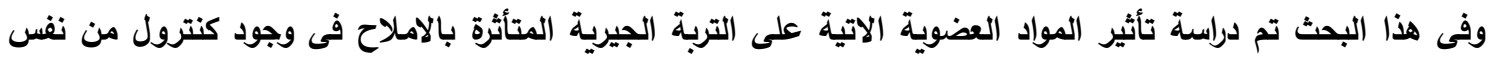

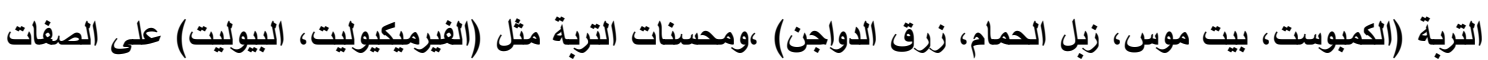

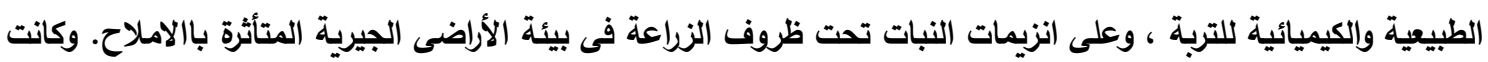
أهم النتائج وجود نمو منخفض لنبات الطماطم انخفاضاً معنوياً ، بالاضافة الى زيادة نثاط انزيم السوبر اكسيديز لئل

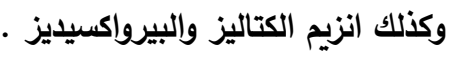
كلمات مفتاحية: برج العرب، التربة الجيرية، انزيم الكتاليز(CAT) و انزيم السوبر اكسيديز دسماتيز(SOD) والبيرواكسيديز (POX).

كلية الزراعة - جامعة الاسكندرية كلية الزراعة - جامعة المنوفية

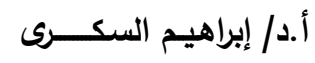

أ.د/ محمد حمادة شلبى 
